Die Gedichte Walthers von der Vogelweide 



\section{Die Gedichte \\ Walthers von der Vogelweide}

Urtext mit Prosaübersetzung von

Hans Böhm

I 944

Walter de Gruyter \& Co.

Berlin 
Archiv Nr. 346r 44

Druck von Walter de Gruyter \& Co., Berlin W 35 vormals G. J. Gosschen'sche Verlagshandlung - J. Gutterntag, Verlagsbuchhandlung - Georg Reimer - Karl J. Trübner Veit \& Comp.

Printed in Germany 
Carl von Kraus und dem Andenken meiner Lehrer Wilhelm Wilmanns und Gustav Roethe dankbar zugeeignet 
